\title{
PossibILIDADES INTERPRETATIVAS DO CAMPO RELIGIOSO BRASILEIRO:
}

\author{
três perspectivas complementares \\ INTERPRETATIVE POSSIBILITIES OF BRAZILIAN RELIGIOUS FIELD: THREE \\ COMPLEMENTARY PERSPECTIVES
}

Elio Roberto P. S. Filho

\begin{abstract}
Resumo A interpretação do campo religioso brasileiro tem sido feita por meio de diversos enfoques interpretativos. Cada um visualiza de forma complementar o fenômeno da religiosidade na sociedade contemporânea, a partir de determinada perspectiva. O presente artigo propõe uma reflexão sob três perspectivas, admitindo-se como pressuposto a complementaridade entre elas, em detrimento do caráter irredutível de cada uma. Destaca-se, assim, um panorama dessas perspectivas analíticas, mostrando suas pertinências para o estudo das religiões no Brasil.
\end{abstract}

Palavras-chave campo religioso brasileiro; modernidade; identidade.

Abstract The interpretation of the Brazilian religious field has been made through various interpretative approaches. Each one displays a complementary manner the phenomenon of religion in contemporary society from a particular perspective. This article proposes a reflection on three perspectives, as a precondition for assuming complementarity between them over the irreducible character of each. It is noteworthy, therefore, an overview of these analytical perspectives showing their relevance to the study of religions in Brazil.

Keywords Brazilian religious field; modernity; identity.

\section{INTRODUÇÃO}

Este artigo tem por finalidade analisar o campo religioso brasileiro a partir de três categorias de perspectivas. Dessa forma, reflete-se sobre a existência de um

a Doutorando em Ciência da Religião pela Universidade Federal de Juiz de Fora (UFJF), área de Ciências Sociais da Religião. 
"fundo" religioso comum determinante, sobre a evidência de uma modernidade ao revés e sobre novas expressões identitárias. A intenção é mostrar, de forma sintética, o dinamismo interpretativo das religiões no Brasil e suas consequências para algumas teorias analíticas, como a da secularização e a do individualismo religioso.

O contexto religioso brasileiro é deveras complexo para ser encaixado em uma única perspectiva de compreensão. Assim, este artigo propõe um diálogo com essas três perspectivas, destacando, ao mesmo tempo, três chaves interpretativas que possam melhor elucidar as mudanças nesse campo, a saber, pelo conceito de pós-modernidade, de culturas híbridas e de reordenamento da sociedade civil em detrimento da teoria da secularização.

As limitações dessa discussão se fazem sentir pela impossibilidade de tratar de todo o campo religioso. Destarte, nem todas as religiões serão analisadas, ficando este artigo balizado no exemplo dos pentecostais, dos neopentecostais, da renovação carismática católica e das religiões afro-brasileiras. Ademais, esse balizamento não encerra todas as características e os eventos dessas manifestações religiosas, mas as retoma principalmente pelo impacto que tiveram nas Ciências Sociais e pela existência de grande material disponível sobre seus movimentos na sociedade contemporânea.

De forma a delimitar esse material, estabelece-se doravante um recorte analítico sobre o campo religioso brasileiro, produzido após a década de 1980, o que permite destacar com mais afinco algumas abordagens e algumas linhas mestras que não encerram todo o objeto, mas têm se mostrado centrais nas discussões sobre os fenômenos religiosos no Brasil.

\section{MATRIZ RELIGIOSA E HOLISMO}

Euclides da Cunha, ao tentar compreender quem era o sertanejo, essa síntese das três raças no Brasil, não pôde deixar de destacar a resultante religiosa que nele se encontrava. A religião indígena, a africana e a católica, todas se misturavam para formar o imaginário simbólico de um tipo humano verdadeiramente brasileiro. Seu biologismo via nesse sujeito rural, em um primeiro momento, um bárbaro, porém forte; apesar da parcimônia física, um corpo adaptado ao meio, uma síntese quase perfeita do amálgama brasileiro.

Nas palavras do autor:

A sua religião é como ele (o sertanejo) - mestiça. 
Resumo dos caracteres físicos e fisiológicos das raças de que surge, sumaria-lhes identicamente as qualidades morais. $\mathrm{E}$ um índice da vida de três povos. $\mathrm{E}$ as suas crenças singulares traduzem essa aproximação violenta de tendências distintas. É desnecessário descrevê-las. As lendas arrepiadoras do caapora travesso e maldoso, atravessando célere, montando em caititu arisco, as chapadas desertas, nas noites misteriosas de luares claros; os sacis diabólicos, de barrete vermelho à cabeça, assaltando o viandante retardatário, nas noites aziagas das sextas-feiras, de parcerias com os lobisomens e mulas-sem-cabeça notívagos; todos os mal-assombramentos, todas as tentações do maldito ou do diabo - este trágico emissário de rancores celestes em comissão na Terra; as rezas dirigidas a S. Campeiro, canonizado in partibus, ao qual se acendem velas pelos campos, para que favoreça a descoberta de objetos perdidos; as benzeduras cabalísticas para curar os animais, para "amassar" e "vender" sezões; todas as visualidades, todas aparições fantásticas, todas as profecias esdrúxulas de messias insanos; e as romarias piedosas; e as missões; e as penitências... todas as manifestações complexas de religiosidade indefinida são explicáveis (CunHA, 2005, p. 73-74).

A figura de Antônio Conselheiro é o exemplo típico da religiosidade popular desse evento histórico. De posse apenas de suas palavras, conseguiu conduzir um expressivo contingente populacional até os confins do sertão nordestino, na promessa de uma esperança a um povo desprovido de auxílio e de reconhecimento. O papel simbólico de conselheiro, visto pelos "civilizados" como antirrepublicano, mostrou que ele acionava uma religiosidade latente, trazendo à superfície aquilo que estaria nos corações, ou melhor, na raiz da sociedade brasileira.

Faz-se necessária, nesse ponto, uma ressalva a essa perspectiva euclidiana. Em sua percepção, há uma fusão no tempo e no espaço entre raça, cultura e natureza que faz emergir um tipo brasileiro sui generis: o sertanejo do Nordeste do Brasil. Sua visão está marcada pelo biologismo que permeava as ciências sociais da época, visão essa superada pelo culturalismo subsequente, que permitia ao autor afirmar que o sertanejo que analisou era o tipo social melhor adaptado ao meio ambiente circundante. Suas qualidades morais e, portanto, religiosas, são resultantes da mistura das raças da qual é fruto. Há, pois, uma relação direta entre mestiçagem racial e sincretismo religioso em Euclides, sendo esta a resultante moral daquela.

A preocupação em explicar a singularidade da formação do Brasil exigia considerá-lo uma nação sui generis, onde essas duas características se deram de forma específica, em oposição ao exemplo europeu. Daí a necessidade de se explicar 
o que significava ser um país de mistura e como era permissível se estabelecer uma identidade mais próxima possível de uma unidade.

A perspectiva euclidiana se soma a um conjunto de análises de diversos autores brasileiros do início do século XX que buscavam explicar o que era o Brasil, questão de inspiração ontológica que teve diversas influências de correntes teóricas do exterior. Influenciado, por exemplo, pelo culturalismo estadunidense está Gilberto Freyre, que deixou ricas análises sobre o amálgama racial e religioso brasileiro pelo viés cultural. Mas quais serão os limites e as possibilidades desse fundo comum religioso? Em que sentido se pode falar da existência de uma religiosidade que perpassa o tempo, desde a formação do Brasil até os dias atuais?

Para equalizar as possíveis respostas a essas perguntas, é necessário concentrar-se no argumento inicial sob a ótica do sincretismo religioso, destacando primeiramente Pierre Sanchis (1998), um autor que insere dois dilemas no campo religioso brasileiro: o dilema da diversidade e o da homogeneidade. Em um tempo em que não é mais possível tratar a religião católica como gestora da vida social e religiosa no Brasil, a pluralidade de crenças se faz sentir sob o signo da oferta múltipla de bens simbólicos. A Instituição Igreja não representa mais o centro regulador religioso, mas aparece como uma instituição ao lado das outras, quando o indivíduo escolhe seu pertencimento e não mais é obrigado a pertencer.

O movimento de diversificação religiosa é acompanhado pela escolha individual do crível. A cultura moderna que remodela a posição do indivíduo diante do leque de opções religiosas insere a possibilidade de escolha como premissa do convívio social.

Pode-se considerar nesse contexto duas figuras sociológicas, a saber, a do peregrino e a do convertido de Hervieu-Leger (1999). O tipo peregrino é aquele que, a partir de suas experiências pessoais, estabelece seu movimento religioso. Ele atravessa a história de todas as grandes religiões, mas encontra seu auge na modernidade. O convertido, em contraposição, representa a figura da formação das identidades religiosas nesse contexto. Esses dois tipos servem como exemplo ideal do pertencimento religioso nas épocas atuais, em que a tradição passa a não mais determinar o sentido do todo social, e as subjetividades no mundo contemporâneo passam a exercer o centro da atividade religiosa por meio de uma religião do coração, aquela que se adapta melhor ao indivíduo.

Ao lado do panorama da diversidade, Sanchis (1998) encontra uma relativa homogeneidade religiosa, "certo clima espiritualista" que permeia a sociedade brasileira. No mais profundo de nossa sociabilidade, um conjunto de significados religiosos de caráter pré-logico é compartilhado pelos brasileiros como parte da 
linguagem comum de todos. Isso não significa, de acordo com Sanchis (1998), a ausência de conflito religioso - o sincretismo não significa tolerância. Essa espiritualidade comum se conjuga na própria cultura vivida e transmitida. Sua razão de ser é dada a priori no convívio social.

A relação entre diversidade e homogeneidade no campo religioso brasileiro deve ser vista sob duas perspectivas. A primeira nos permite ver no enfraquecimento das instituições a abertura à diferenciação religiosa, ao novo e à criação. A segunda nos remete à questão da existência de um fundo comum religioso que permanece no mais profundo da sociedade brasileira.

Dessa constatação, Sanchis (1998) designa como holismo esse fato emblemático da religiosidade nacional. O sincretismo religioso que se deu no Brasil superou, mutatis mutandis, blocos fechados de crenças, tendo como síntese uma forma sui generis do crível. Como consequência disso, Sanchis (1998, p. 40) chama atenção à existência de um habitus sincrético, de um pertencimento poroso aos conteúdos religiosos.

Segundo Bourdieu (2001), o habitus é uma possibilidade, ou seja, implica uma tendência. As condições objetivas, quando incorporadas subjetivamente, inserem uma forma probabilística da ação. O corpo, a hexis, encerra a condição objetiva da sociedade no indivíduo. Significa uma reelaboração da dialética do processo social e da relação entre indivíduo e sociedade.

Um outro autor que explana sobre a ideia de uma relativa homogeneidade no campo das religiões no Brasil, Bittencourt Filho (2003), denomina como matriz religiosa brasileira esse substrato religioso comum que permeia a sociedade nacional. Fruto de uma construção histórica e dinâmica, essa matriz exerce um fator condicionante em todas as religiões que venham a se estabelecer nesse território e nas anteriormente estabelecidas. Com efeito, segundo o autor, o êxito e o fracasso dessas religiões estão ligados ao nível dialógico dessas crenças com esse substrato religioso. Ou seja, tanto pela contestação como pela incorporação dessa matriz, a dinâmica das velhas e novas religiões é dependente dessa relação - inevitável - e por ela tende a balizar seu conteúdo.

Ainda contextualizando sobre a existência de um fundo religioso brasileiro, Droogers (1987) chama de "religiosidade mínima" aquela que transcende as instituições, encontrando-se no cotidiano da vida social, na esfera pública e no meio secular. Em síntese, ela está na cultura. Nesse ponto de vista, há uma religiosidade geral integrada na sociedade que está nos discursos e na comunicabilidade dos sujeitos. Como faz parte da cultura, ela está dentro de uma teia de significados, nos termos de Geertz (1989), e, portanto, está diante de um contexto de sentido. 
Separar, nesse caso, religião e cultura se torna algo difícil, pois a ideia de religiosidade mínima permite estabelecer uma nova relação entre esses dois conceitos. Pensá-los de forma substantiva como dois blocos distintos e autônomos pode significar separar o que é inseparável - no caso brasileiro. Sanchis apresenta essa preocupação, pois, segundo ele:

A religião teria, então, a ver com a cultura? Dir-se-ia: tudo a ver. E tudo o que se acabou de dizer da cultura, inclusive a mudança contemporânea na sua situação real e na sua apreensão teórica, poderia analógica - ou metonimicamente aplicar-se à religião. A religião também pretende fornecer ao ser social uma visão do mundo - uma representação particular, com suas categorias próprias, que torna o mundo intelectual e emocionalmente apreensível (Deus, deuses, orixás, anjos, santos, criação, congregação, igreja, autoridade, verdade...). Tudo isso compõe um mundo particular e o organiza e tudo isso, para o fiel, faz do mundo genérico o seu mundo. Como o faz a cultura. Mas, além disso, a religião maneja categorias que atingem a subjetividade do fiel neste mundo, impulsionam sua ação, orientam e qualificam o seu comportamento externo e suas atitudes profundas (dependência, oração, louvor, sacramento, magia, pecado ou simplesmente erro, o sentido, afinal, do comportamento): um motivo para viver e um modelo para a vida (SANCHIS, 2008, p. 76-77).

Diante dessa complicada separação entre cultura e religião no Brasil, observa-se que a religião, mesmo se constituindo como cultura, guarda uma distinção essencial entre ela e uma outra ordem de fatores:

Sagrado ou Deus, em todo caso um sistema, que confere sentido ao mundo e à existência humana e que visa um absoluto. É nesse sentido que a religião se constitui como uma cultura, que é mais que cultura. Elevada ao quadrado (SANCHIS, 2008, p. 78).

A matriz religiosa brasileira pode ser entendida, portanto, como uma remodelação dessa relação sob o signo do sincretismo e do habitus sincrético. A dificuldade de se pensar cultura e religião em separado demonstra a singularidade de uma sociedade fundada na conjugação de uma pluralidade religiosa. A tríade racial da formação brasileira, o índio, o negro e o branco, e no campo da religião, a difusa religiosidade indígena, as religiões afro e o catolicismo romano, determinaram a 
origem da formação desse substrato. Dessa forma, sincretismo e miscigenação são dois alicerces da formação cultural nacional.

Contudo, é preciso ainda mencionar que, como afirma Carvalho (1992), há certa incomensurabilidade entre as religiões. Há fronteiras no imaginário religioso que não tendem a ser tão flexíveis ou somente o são de forma superficial. Se sincretismo não significa tolerância; nessa ótica, não significa também uma total fusão. Esse clima espiritualista que representa a relativa homogeneidade do campo religioso nacional se seguiu por uma remodelação entre três momentos, a saber, a pré-modernidade, a modernidade e a pós-modernidade.

Sanchis (1998), nesse contexto, demonstra que no Brasil a relação temporal entre esses momentos se desfaz ao se relacionarem na contemporaneidade. Pensá-los presos a épocas específicas reduz o valor analítico da aplicação de seus conteúdos. Se, na atualidade, essas formas tendem a se intercruzar, com o moderno retomando ao tradicional para expressá-lo modernamente e o pós-moderno dialogando com o déficit da modernidade e com os pilares da tradição, faz-se mister vê-los como estilos de vida mais do que marcadores de época (Silveira; CROCHet, 2006). O diagnóstico da porosidade das fronteiras é contraposto por novas afirmações identitárias, daí o dilema entre religião institucional e religião individual, tradição e modernidade, que confluem no panorama atual da diversidade.

Cada vez mais a religiosidade mínima, a matriz religiosa e o holismo que perpassam a sociedade brasileira se deparam com as novas rupturas e continuidades no campo religioso. Sob o prisma da pós-modernidade, todo o ponto fixo que permitia a segurança individual tende a ser colocado em evidência. Segundo Bauman (1998), nesse momento há mais liberdade e menos segurança, enquanto antes havia um pouco de segurança à custa de um pouco de liberdade. Nesse sentido, qual pode ser ainda o papel desse fundo religioso que está na cultura e como ele repercute nesse clima de instabilidade típico da época em que vivemos? Antes de refletir sobre essa pergunta, é preciso contextualizar que tipo de modernidade à brasileira houve no campo das religiões, identificando alguns de seus traços específicos.

\section{UMA MODERNIDADE AO REVÉS?}

A tese sobre o movimento inevitável de secularização no ocidente tem sido questionada pelos trabalhos recentes sobre o campo religioso brasileiro, como será visto neste ponto. Viu-se que a persistência da religião não se reduziu apenas à esfera privada, mas também ao espaço público. Os pentecostais, a renovação 
carismática católica, os movimentos de identidade das religiões afro-brasileiras, os movimentos new age e as religiosidades orientais provocaram um novo despertar religioso sob as bases da modernidade, porque se trata da pós-modernidade. Diante do signo da liberdade de escolha e da diversidade religiosa, o centro da religião se tornou a própria subjetividade. Se, por um lado, as instituições religiosas não mais conseguem a gestão do todo da vida social, elas não saem de cena, porém encontram sua consolidação por meio de outras circunstâncias. Não impõem mais uma verdade objetiva, mas disponibilizam um estilo de vida.

De acordo com Berger (1985), a secularização conduz a uma situação de pluralismo. Quando não é mais possível o monopólio religioso de uma sociedade, o sentido dado às consciências coletivas e individuais se fragmenta pelo enfraquecimento do sentido religioso dado ao ser-conjunto. E essa situação pluralista, segundo o autor, resume uma situação de mercado. Ou seja:

A característica-chave de todas as situações pluralistas, quaisquer que sejam os detalhes de seu pano de fundo histórico, é que os ex-monopólios religiosos não podem mais contar com a submissão de suas populações. A submissão é voluntária e, assim, por definição, não é segura. Resulta daí que a tradição religiosa, que antigamente podia ser imposta pela autoridade, agora tem que ser colocada no mercado. Ela tem que ser "vendida" para uma clientela que não está mais obrigada a "comprar". Situação pluralista é, acima de tudo, uma situação de mercado (BERGER, 1985, p. 149).

Essa mercantilização traz consigo uma forma de experimentação do religioso por meio do consumo. O indivíduo, ao tomar as rédeas de sua escolha em termos de crença, vê-se diante de opções concorrentes, sendo o voluntarismo participativo uma escolha subjetiva. A forma de se experimentar o religioso se torna fruto da interioridade do sujeito. Dessa forma, Caminho da Luz, Caminho das Missões Jesuíticas, Caminho da Fé, Caminho Passos de Anchieta, entre outras rotas religiosas no Brasil e no exterior, como exemplifica Carneiro (2004), são espaços onde o fiel, o peregrino, substancia uma religião do self, onde turismo e sentimento religioso se intercruzam dentro da lógica do consumo.

Diante desse contexto, a tese da secularização que vem acompanhada da consolidação do pluralismo, do mercado e do individualismo religioso aparece como uma forte tendência da modernidade. Foi sob essas novas bases que as crenças tiveram que buscar novas sustentações, daí a racionalização das estruturas religiosas e sua consequente burocratização (BERGER, 1985). 
O papel nivelador da burocracia descrito por Weber (1971), sua impessoalidade e formalização são, em síntese, as características racionais de um sistema moderno de organização. Segundo Berger (1985), isso significa para as religiões uma forma de ecumenismo que é exigido na situação pluralista, em que as competições entre as religiões se racionalizam diante de um mercado de oferta simbólico. Essa é uma necessidade apontada por ele de se racionalizar uma competição diante de um mercado de oferta simbólico. Se antes era possível a eliminação do concorrente pela força, agora é pela competição aberta, dependendo, portanto, das diferentes estratégias dos grupos.

Diante desse panorama clássico dado à situação das religiões na era moderna, o caso brasileiro se mostra instigante e idiossincrático em relação a esse modelo teórico e normativo da secularização. "A religião também está aí, a mesma e outra”, diz Sanchis (2008, p. 89), ao se referir ao emblemático caso brasileiro. As pesquisas recentes mostram a continuidade religiosa que o Brasil vive e também suas descontinuidades ${ }^{1}$. O crescimento pentecostal é o exemplo maior de mudanças no campo religioso brasileiro. A isso se soma o pluralismo católico que sempre existiu e passou a se afirmar mais recentemente pela renovação carismática, pela teologia da libertação e pelo reconhecimento das tradições populares ${ }^{2}$.

Outro ponto a se destacar na tese da secularização é a privatização religiosa. Ao perder seu papel de agenciadora do coletivo, a religião foi renegada à esfera do particular. A religião sai do Estado e passa a não ter mais a influência legítima de gestora do corpo coletivo. E seria o caso francês o exemplo mais fiel desse evento marcante.

A lei de $1905^{3}$, que estabeleceu de vez a cisão entre o Estado e a religião, moldou o Estado laico e definiu, via de regra, os parâmetros para o exercício do religioso naquela sociedade. No Brasil, diferentemente da França, foi a religião católica que serviu como baliza no reconhecimento legal das outras religiões.

Giumbelli (2008) e Montero (2006) mostram como o espiritismo e o candomblé conseguiram se consolidar como religião a partir do reconhecimento legal. O problema dessas duas crenças era que a primeira era acusada de fazer curandeirismo, ou seja, seria uma questão de saúde pública, e a segunda era

1 Pierucci (2006a) ressalta que, mesmo diante da diversidade religiosa existente no Brasil, o país continua predominantemente cristão. O crescimento quantitativo pentecostal é, na verdade, acompanhado por certa igualdade qualitativa em relação ao catolicismo.

2 Steil (2001) mostra o exemplo de duas figuras populares, padre Cícero e Madre Paulina, que tiveram o reconhecimento oficial por parte da igreja católica. Isso significa, nesse caso, uma tentativa do catolicismo oficial de manter e angariar fiéis em uma situação pluralista.

3 Chamada de "Loi du 9 décembre 1905 concernant la séparation des Églises et de l'État". 
acusada de feitiçaria - o que, na época, início do século XX, era visto com um grande exotismo e juízo de valor negativo. Ambas sofriam implicação do imaginário católico, que as determinava como ilegais e profanas, usando, para tanto, de um mecanismo jurídico para impedir suas práticas. A saída encontrada pelo espiritismo foi mostrar que o que fazia se enquadrava na categoria religião ditada pela lei, usando para isso o conceito de caridade advindo do catolicismo. Já as religiões afro-brasileiras se legitimaram como religião mostrando que representavam a cultura nacional original. Dessa forma, usaram códigos disponíveis para se expressar e conseguir reconhecimento público.

A privatização religiosa no Brasil não foi suficiente para reprimir a expressão pública da fé. As tentativas de fazer do catolicismo a religião oficial de um país no contexto do pluralismo resultou em disputas por parte de outras religiões por representação no espaço público. Fato marcante desse momento foi o manifesto protestante de 1932, que representou a preocupação em plena era Vargas de uma sociedade livre, um Estado laico em suas instituições, que não favorecesse uma religião específica - ou seja, a religião católica.

As novas religiões que passam a compor o campo religioso brasileiro no final do século XIX e início do século XX, a saber, o protestantismo e o espiritismo ${ }^{4}$, buscam posicionar-se no espaço público por meio de centros educacionais e instituições filantrópicas, sucessivamente. Mas será a partir da década de 1950 que o espaço religioso será remodelado pelo crescimento vertiginoso dos pentecostais e por sua expressão na mídia e na política.

É relevante lembrar que a entrada pentecostal no Brasil se refletiu em uma negação da cultura tradicional. Ser pentecostal era não ser católico (NovAEs, 1985), e a identidade se dava pela negação, sendo, portanto, relacional. O indivíduo convertido era aquele que refletia sobre a cultura herdada para rejeitá-la, por meio de um novo discurso. O pentecostalismo foi a religião que se expressou pela oposição em relação à cultura nacional, tendo presença tanto nas grandes metrópoles quanto nas zonas rurais.

É importante ainda mencionar o grande crescimento quantitativo dessa manifestação religiosa. Os dados do censo de 2000 mostram que os que se consideraram pentecostais foram 17 milhões, representando 10,43\% do universo de evangélicos. Nota-se que o aumento do número de evangélicos foi concomitante à diminuição, em termos percentuais, dos que se declaravam católicos. Estes, que em 1991 eram

4 Ainda há as tradições esotéricas que entram no campo religioso nessa época, mas com um impacto menor do que teve o protestantismo e o espiritismo. 
$83,8 \%$ da população, passaram a ser, em 2000, 73,8\%, e os evangélicos passaram de $9,05 \%$ para $15,45 \%$ da população.

Mais do que uma visibilidade em números, os pentecostais conseguiram uma consolidação no Brasil, que, a um primeiro olhar superficial, poderia ser visto como uma volta à religião ou como um revigoramento do fator religioso na sociedade brasileira. Mas é preciso, antes dessa constatação, olhar as entrelinhas desse fenômeno e observar a forma como se inseriram no cotidiano do espaço social.

A primeira característica do fenômeno pentecostal é a segmentação denominacional. Diversas vertentes desse ramo do protestantismo se fazem sentir no meio social e exprimem uma tendência à divisão. Inspiram uma forma de instabilidade cismática que permite a criação constante de novas igrejas, onde o indivíduo tem a possibilidade de criar, por vontade própria, um novo templo e recaracterizá-lo à vontade do grupo envolvente.

No nível interno da crença, o pentecostalismo se caracteriza pela primazia dos dons do Espírito Santo (MAFrA, 2001). Aí se encontram a glossolalia, o profetismo e a cura. Mais do que isso, ele trouxe uma nova forma de expressar a palavra por meio da informalidade e da simplicidade, que se contrapunham ao rigor formal de muitas igrejas históricas. Atingindo principalmente as camadas populares, essa manifestação religiosa logo foi interpretada como de caráter mágico, principalmente com o surgimento dos chamados neopentecostais, com o aparecimento da Igreja Universal do Reino de Deus e de seus rituais de prosperidade e exorcismo.

Nesse ínterim, a relação entre modernidade e racionalidade remete a posturas clássicas diante do assunto. Na interpretação de Weber, por exemplo, uma das formas de se compreender a racionalidade de uma sociedade é observar seu afastamento da magia (WEBER, 1974, p. 263). Quando o caráter causal de um evento é remontado a causas invisíveis, ou supra-humanas, e quando há pensamento por analogia e por contágio - duas dimensões do pensamento mágico -, a realidade objetiva não apresenta uma inteligibilidade em si. Dessa forma, seria uma contraposição ao pensamento racional, símbolo do movimento intelectual ocidental, que desembocou na secularização tanto da vida quanto da sociedade.

Outra característica relevante que é importante ressaltar é o reengajamento prático-institucional que tem acontecido em algumas religiões no Brasil. Mariz e Machado (1998) pontuam esse fato dando como exemplo os fiéis de igrejas pentecostais e da renovação carismática católica. Pode-se observar uma nova forma de compromisso institucional que instala novas possibilidades de afirmação identitária. Desse modo, as autoras refutam a hipótese de Prandi de que isso resulta 
de uma mudança de consumo de bens mágicos. Na verdade, segundo elas, essa é uma constatação preliminar. É preciso observar com mais profundidade a inserção do fiel no contexto da religião, pois a motivação inicial por parte dos "clientes religiosos" pode evidenciar a procura - consumista - pragmática de alguma solução para algum problema. Segundo as autoras, é preciso atentar-se às pressões para que o indivíduo permaneça no grupo pela conversão. Será por meio desse processo, nem sempre perfeito, que o consumo de bens simbólicos abrirá espaço para a participação efetiva. Daí que o indivíduo pode permanecer na instituição e estabelecer sua prática religiosa dentro da estrutura coletiva, compartilhando, assim, ideais éticos.

Outro fato marcante que tem ocorrido nas religiões pentecostais e neopentecostais é a "mitigação do caráter transcendental da opção autônoma”, responsável e modernamente constitutiva da pessoa e da consciência, pela importância reconhecida e coletivamente ritualizada do fator demoníaco: "Não é você; é o demônio que está em você" (SANchis, 1998). A bandeira do indivíduo moderno que toma para si o centro de suas atitudes agora se vê em sua despersonalização em face dos acontecimentos. A demonização da pessoa significa que os atos - pensados pela modernidade como centralizados no sujeito - advêm de uma "entidade maligna". Convém perceber que apenas pelo exorcismo o indivíduo pode retornar como dono de si, mas estando sempre propenso a uma nova possessão e mais uma vez a uma não intencionalidade do self.

Pontuando de forma mais precisa, o crescimento dos pentecostais, a nova expressão pública das religiões, a retomada da magia em grandes rituais religiosos, o reengajamento institucional e a desindividualização fazem indagar que tipo de modernidade aconteceu no Brasil. As mudanças recentes do campo religioso brasileiro demonstram que o projeto da modernidade construído na Europa, formado por dois pilares, nas palavras de Santos (1997) ${ }^{5}$, a saber, o da regulação e da emancipação, é deficitário quando relacionado com o panorama contemporâneo.

Seria plausível pensar em uma modernidade ao revés quando se observa a configuração religiosa no Brasil contemporâneo? Dentro de qual chave interpretativa pode-se tentar compreender as religiões no Brasil? Uma proposta seria pela ideia de pós-modernidade, em que o fim das grandes narrativas e a nova relação

5 Segundo Santos (1997), o projeto cultural da modernidade se pautava no pilar da regulamentação, em que o Estado (Hobbes), o mercado (Locke) e a comunidade (Rousseau) estariam ligados ao pilar da emancipação, ou seja, da racionalidade estético-expressiva (arte), da racionalidade moral-prática da ética e do direito e da racionalidade cognitivo-instrumental da ciência. Segundo ele, a grande armadilha da modernidade foi transformar as energias emancipatórias em reguladoras. 
do indivíduo com a pluralidade demonstram a contradição da modernidade. A valorização da emoção, as identidades múltiplas, a atualização das tradições e os eventos da vida cotidiana influem na percepção do limite do projeto moderno.

Outro eixo interpretativo tem origem na ideia de culturas híbridas de Canclini (Silveira; Crochet, 2006). Esse é um termo melhor adaptado ao contexto latino-americano por considerar a singularidade da formação social e cultural desse território. Nos países latinos, as dicotomias subalterno/hegemônico, tradicional/ moderno, entre outras, precisam ser repensadas pelas características específicas do continente. Destarte, é preciso ver na hibridação um processo de mistura que relaciona mercado, arte, etnias e tradições dentro de um novo contexto.

Outra proposta de interpretação que considera a especificidade do caso brasileiro é apresentada por Montero (2006), que, em substituição à teoria da secularização, retoma a noção de sociedade civil advinda de Habermas para pensar a alocação da magia na sociedade contemporânea. Segunda a autora, o desaparecimento da magia não se seguiu conforme a propunha o movimento de secularização, em que a sociedade racional proclamaria sua autonomia em face da irracionalidade. Mas, ao analisar o caso do Brasil, onde o Estado se pautava na religião católica como parâmetro ideal de religião, provou que a magia, em vez de ser ejetada da sociedade, foi reafirmada em novos espaços. Esse processo foi influenciado pelo próprio Estado, que lhe deu um novo status, mesmo que não intencionalmente. Um exemplo dado foi o que ocorreu com o candomblé, como supramente descrito, quando acusado de ser feitiçaria.

Montero deixa claro que, se for compreendido esse evento pela formação da sociedade civil brasileira, não se estará sendo reducionista, como o que acontece com a teoria da secularização. Assim, será possível observar o novo papel que a magia assume na sociedade, em vez de forçar seu desaparecimento teórico.

Essas três chaves interpretativas do campo religioso brasileiro podem dar uma compreensão mais atenta da especificidade e do contexto das religiões no Brasil. Elas serão exemplificadas no ponto seguinte. Por ora, ressalta-se que as transformações que ocorreram na modernidade, e ao contrário do que foi proposto em moldes teóricos pela vanguarda iluminista e por outros autores subsequentes, solapou as perspectivas de um mundo secularizado e racionalizado, onde o indivíduo representasse a centralidade atuante. Mais uma vez retomando Sanchis, as religiões estão aí, atualizando a tradição e modernizando-se ao mesmo tempo. O caso brasileiro é exemplar nesse sentido, em que a dinâmica das religiões não cessa de trazer novos problemas analíticos. 


\section{HARMONIA, CONFLITO E AFIRMAÇÃO IDENTITÁRIA}

A constatação de que há uma diversidade religiosa no Brasil contemporâneo precisa ser seguida de uma melhor apreciação da dinâmica da permanência das diversas religiões. Para que seja possível observar como esse leque de opções simbólicas se torna acessível aos indivíduos, é preciso entender como as religiões se estabelecem no campo religioso e como as identidades são construídas.

Para uma limitação heurística, pode-se tomar o exemplo de quatro manifestações religiosas: o pentecostalismo, o neopentecostalismo, a renovação carismática católica e as religiões afro-brasileiras. Esse recorte foi feito tendo por base o impacto que essas religiões tiveram para a produção atual das ciências sociais e também pela dificuldade de se buscar uma síntese mais ampla do campo religioso brasileiro sem cair no reducionismo extremo, visto a numerosa diversidade e complexidade das crenças.

As três ondas do pentecostalismo no Brasil apresentadas por Freston (1993) mostram a sequência denominacional que se instalou até o surgimento dos neopentecostais. A Igreja Universal do Reino de Deus é o ápice de um fenônomeno que se iniciou no princípio do século XX, com a entrada desse tipo de protestantismo no Brasil. No campo simbólico, os pentecostais eram munidos de um discurso de santificação e separação das "coisas do mundo" (Novaes, 1985). De acordo com Mafra:

Na visão holística crente, nem corpo, nem alma, nem espírito - essas três categorias constituintes dos seres humanos - têm propriedades infinitas. Entretanto, o aprendizado e a convivência da limitação é trabalho complexo e envolve uma busca (individual e congregacional) denominada "santificação". Nessa busca, o espírito, por ser capaz de apreender o infinito, tem uma função central na medida em que promove o conforto diante da limitação. Em decorrência, nesse paradigma dificilmente haverá renovação do corpo e da relação humana (cura) sem conversão religiosa (MAFRA, 2001, p. 68-69).

Aqui, pode-se observar o papel central que a comunidade religiosa substanciada na instituição tem como articuladora da santificação e da conversão. Destaca-se que o processo da conversão é um momento em que há um aprendizado, pois o neófito precisa aprender como crer (Alves, 2005).

Como foi anteriormente mencionado, os pentecostais negavam em seu proselitismo a cultura herdada, que englobava a religião católica, sendo então uma crença 
por oposição. Mais do que negar o catolicismo como tradição, negavam qualquer outra forma de religiosidade popular, e principalmente o espiritismo (MACHADO; MARIZ, 1994) e as religiões afro-brasileiras (SoAREs, 1993). Mas é com os neopentecostais que o conflito religioso toma uma expressão mais acentuada, vista como uma guerra santa, em que as entidades do mal estão em batalha constante com o povo santo. Entra em cena o papel do exorcismo público e a performance da manifestação pública da figura maligna que é preciso expulsar. Mas, para tanto, é preciso reconhecer a figura do mal em princípio, para depois reprimi-la através dos rituais sagrados:

Suprimidas e negadas, mas reconhecidas, mencionadas, incorporadas. Este ponto é decisivo: o pentecostalismo exige a pureza doutrinária e rejeita práticas e crenças que as camadas populares cultivam sobretudo na Umbanda, na Quimbanda, no Candomblé. Entretanto, invocam as presenças de Exu, e Pomba Gira nos rituais de exorcismo que promovem. Os praticantes de religiões afro-brasileiras em processo de conversão para o pentecostalismo, em algumas de suas versões, são instigados a receber o santo ainda uma vez, no templo que os acolherá a partir da conversão. A crença que se abandona é interpretada pelo pastor oficiante. Em outras palavras, a existência das entidades espirituais que povoam os credos afro-brasileiras é reconhecida (SOARES, 1993, p. 205).

Se os pentecostais e neopentecostais reconhecem a presença do "inimigo" e assim confirmam a existência do "outro", o conflito age como uma afirmação e como uma negação ao mesmo tempo. O "eu", nesse caso, precisa ser fortalecido pelo Espírito Santo para que o inimigo não se apodere do "santuário de Deus" (SILvA, 2005). A batalha espiritual se torna então um combate simbólico entre as dimensões maniqueístas do bem e do mal, em que o sujeito se torna o receptáculo de uma guerra, que é individual, e a qual faz tornar pública no papel do adorcismo e do exorcismo.

Mas esse conflito espiritual é seguido de cruzamentos cosmogônicos que permitem ver a outra dimensão dessa relação. A simbologia utilizada pelos neopentecostais incorpora entidades das religiões afro-brasileiras, expressando-as em um novo contexto. É preciso considerar, como afirma Silva (2005), que a batalha dos neopentecostais contra os terreiros tende a demonstrar, em um primeiro momento, um afastamento entre essas instituições, mas, ao aprofundar na trama simbólica em jogo, é possível ver algumas aproximações substantivas entre as duas crenças. 
É criada quase uma religiosidade ao inverso, pois quando as entidades são desterritorializadas, o Exu vira diabo e o transe ocorre pela possessão do Espírito Santo.

Se for retomada nesse ínterim a noção de culturas híbridas de Canclini (2006) como chave interpretativa para interpretar o fenômeno pentecostal e neopentecostal, perceber-se-á que essa mistura - hibridação - com as manifestações católica e afro-brasileira confluiu em uma síntese religiosa bem adaptada ao solo nacional. A proposta de Canclini é que se observem esses eventos além de seus paradoxos imediatos, visualizando, antes, possibilidades de formação sui generis. Essa chave interpretativa busca ser mais condizente com a realidade dos países latinos que experimentaram uma modernização tardia e diferente dos moldes europeus.

Por outro lado, apesar da oposição que as religiões afro-brasileiras têm sofrido pelos pentecostais e neopentecostais, elas não sucumbiram no campo religioso brasileiro e buscaram novas formas de afirmação identitária. Há uma tentativa de restauração de sua pureza que abandona a ideia de religião étnica em detrimento de uma religião de caráter universal. Nas palavras de Pierucci (2006b, p. 23):

A umbanda, como sabemos, desde o princípio se auto-representou como dirigida a todos os brasileiros: negra, índia e branca, the Unbanda is for all of us. Assim foi desde o berço, melhor, desde a concepção, pois ela não foi concebida nem como uma religião negra nem muito menos como uma religião só de negros. Já o candomblé, este sim concebido como "uma religião de preservação do patrimônio cultural específico do negro", com o passar do tempo, foi, por sua vez, “constituindo-se em religião para todos". E foi assim que na segunda metade do século XX ele se espalhou pelas grandes cidades brasileiras, muitas das quais no Sudeste, onde antes dos anos 1960 ele não passava de uma referência cultural regional para quem voltasse os olhos curiosos em direção à Bahia.

Essa universalidade das religiões afro-brasileiras é seguida de uma abertura identitária para o pertencimento múltiplo. Como um fato moderno, essa universalização amplia o horizonte de recrutamento de seguidores. Isso significa que ser negro ou descendente de escravos não é mais condição sine qua non para pertencer a essa religião. Até porque, como mostra Pierucci (2006b), as religiões pentecostais têm absorvido um contingente significativo da população negra que participava dos cultos afro-brasileiros, demonstrando que o trânsito religioso implica também deslocamento racial. 
À universalização religiosa, segue Pierucci (2006b), junta-se o individualismo. Uma religião para todos prescreve que os indivíduos estejam dissociados e que, a partir da livre escolha, possam decidir por sua participação religiosa. No caso das religiões afro-brasileiras, isso significa que a identidade africana e étnica não mais determina a presença nos cultos: ela se circunscreve como puramente religiosa.

Nesse caso, a chave interpretativa do conceito de pós-modernidade permite observar esse fenômeno como fruto de um contexto de mudanças identitárias e transposição das grandes narrativas, ou seja, a identidade africana que ligava muitos dos membros do candomblé passa a ser questionada na umbanda, que permite uma abertura participativa independente da herança étnica. Essa atualização da tradição é um evento típico da chamada era pós-moderna.

Outro caso de transformação identitária ocorre no catolicismo por meio da renovação carismática. Mais do que uma nova forma de experimentação da religião católica, ela tem fortes interfaces com o pentecostalismo. Em síntese, as principais semelhanças, de acordo com Machado e Mariz (1994), são uma maior participação e autonomia dos leigos, uma articulação do encantamento/sobrenatural com a ética e uma religiosidade emocional. A escolha individual faz parte da afirmação identitária, representando uma escolha racional. O culto show, as bandas de músicas e a glossolalia são algumas características que compõem as duas manifestações religiosas.

Como a pluralidade do universo católico é um fato histórico, sua segmentação não ocorreu como no protestantismo. Como uma religião virtualmente englobadora e sincrética, conseguiu colocar dentro a diversidade, sem, contudo, perder seu centro. A figura do papa é permissiva em boa parte do catolicismo, visto que as outras formas de cristianismo - católicos - foram reconhecidas e circunscritas pela instituição oficial. Isso se deu como estratégia para a religião se manter expressiva e não perder fiéis.

Mas entre os fiéis da renovação carismática católica, o trânsito religioso em igrejas pentecostais é um fato marcante que os distingue dos pentecostais em relação a essa reciprocidade. Mariz e Machado (1998), em outro artigo, mostram que a liderança católica tem elaborado estratégias para estabelecer fronteiras e combater o movimento de idas e vindas de seus integrantes. São elas o marianismo, a valorização dos sacramentos e o estímulo com relação ao Santo Papa.

Pode-se, por sua vez, explicar esse fenômeno pela chave interpretativa colocada por Montero, que insere recursos analíticos alternativos aos da teoria da secularização. Segundo essa lógica, a procura pela experiência mágico-religiosa por parte dos fiéis e seu reengajamento institucional mostram uma intensificação 
da vivência religiosa ao invés de seu afastamento. Um exemplo disso foi a perda da força da teologia da libertação, marcada por sua racionalidade política, em detrimento do aumento expressivo da renovação carismática católica, marcada pela experiência emocional. Essa vitalidade religiosa pode ser percebida como fruto de um reordenamento do campo religioso brasileiro e da sociedade civil brasileira, como propõe Montero, e não necessariamente como um processo de secularização mal resolvido.

As três chaves interpretativas expostas neste artigo não encerram em si todas as possibilidades analíticas do campo religioso brasileiro. Na verdade são complementares entre si e têm a virtude de serem permissíveis de aplicação em diversos fenômenos observáveis. Os exemplos aos quais foram aplicados podem ser vistos também por outras óticas interpretativas. No entanto, ressalta-se que a pluralidade interpretativa funciona muito mais como recurso heurístico do que imprecisão teórica, permitindo análises e perspectivas dinâmicas do objeto.

Com efeito, o campo de forças simbólico se concretiza na emergência dessas estratégias e consolida cada vez mais a situação de pluralismo que permeia a sociedade brasileira por meio de uma concorrência entre as religiões por intermédio de afirmações identitárias, conflitos e harmonia. O panorama do campo religioso brasileiro é deveras complexo para encerrar-se nessas notas preliminares. "As religiões estão aí”, parafraseando mais uma vez Sanchis.

Em síntese, as três categorias de perspectivas de elucidação do campo religioso brasileiro foram colocadas sucessivamente. De fato, elas se intercruzam e propõem um amplo leque analítico da complexidade de suas características. Observou-se que a constatação de um fundo religioso homogêneo implica olhar a diversidade dentro também da lógica da permanência. Ao estar na cultura, a religião faz parte da teia de significação que lhe confere sentido. Esse holismo que a caracteriza exerce uma dialética com a performance da diversidade dentro do eixo harmonia/ conflito. Destaca-se o exemplo dos pentecostais e neopentecostais e suas relações com as religiões afro-brasileiras. Mas como instrumento analítico, a ideia de uma religiosidade mínima ou matriz religiosa pode ter um déficit explicativo ao dirigir a um passado distante a explicação dos eventos religiosos contemporâneos. As novas religiões que passaram a compor o espaço religioso brasileiro e as recentes formas de manifestação identitária fazem com que haja um diálogo com esse passado de outra forma, seja pelos movimentos de dessincretização, seja pelas novas formas de experimentação do religioso.

Uma "modernidade ao revés" que parece ter caracterizado o campo religioso brasileiro exigiu chaves interpretativas mais sólidas. Assim, a potencialidade analí- 
tica do conceito de pós-modernidade, a noção de culturas híbridas e a utilização do arranjo sociedade civil/Estado em face do modelo da secularização destacam-se pela utilidade elucidativa de explicação desse campo.

Os conflitos entre as religiões traduzem continuidades e rupturas da diversidade religiosa. Essa característica dual das religiões no Brasil perpassa mais uma vez o jogo dialético entre habitus e performance e não deixa de ser instigador em demonstrar as novas atitudes de pertencimento em uma sociedade plural. Ademais, é pelo conflito e pela oposição que muitas identidades são modeladas. Caberia, pois, observar os desafios disso para o diálogo inter-religioso ou tentar compreender melhor o que significa a negação da diferença por reconhecimento dentro de uma sociedade democrática fundada, teoricamente, na tolerância e na igualdade.

\section{CONSIDERAÇ̃̃ES FINAIS}

Três abordagens sobre o campo religioso brasileiro foram destacas pela importância analítica. A primeira, a saber, versa sobre a existência de um "fundo" simbólico-religioso comum que perpassa nossa sociedade e foram denominadas pelos autores como holismo, matriz religiosa e religiosidade mínima. Segundo essa perspectiva, existe uma religiosidade cravada culturalmente na sociedade brasileira e imputada como habitus, ou seja, como possibilidade. O questionamento que surge sequencialmente a essa discussão versa sobre a permanência desse fundo religioso em uma época considerada moderna. Logo, perguntou-se que tipo de modernidade tem experimentado o Brasil no campo das religiões, permitindo-se concluir que, diferentemente do modelo europeu, o Brasil vivenciou fenômenos que não foram de encontro com a teoria da secularização. A esse diagnóstico deu-se $o$ nome de uma modernidade ao revés, evidenciada pelo revigoramento das religiões, pelo reordenamento religioso por meio da sociedade civil e a sucessiva alocação da magia na sociedade.

Em seguida, foram destacadas três chaves interpretativas que poderiam ser usadas para abordar o campo religioso brasileiro, considerando os problemas da modernidade. A ideia de culturas híbridas, de pós-modernidade e de reordenamento da sociedade civil em detrimento da teoria da secularização pode ser útil para compreender a dinâmica das manifestações religiosas no Brasil.

Concluindo a última abordagem sobre o campo religioso brasileiro, aquela que versa sobre a análise das identidades religiosas e suas resultantes conflituosas - e também suas alianças harmoniosas -, buscou-se aplicar as três chaves interpretativas propostas de forma a instrumentalizá-las em sua função explicativa. Ademais, 
deu-se ênfase ao caráter complementar das três perspectivas em voga e também das três chaves interpretativas destacadas, expondo, destarte, que a pluralidade de olhares sobre o campo religioso brasileiro pode enriquecer o conhecimento sobre a realidade social das religiões no Brasil.

\section{REFERÊNCIAS BIBLIOGRÁFICAS}

Alves, Rubem. Religião e repressão. São Paulo: Loyola, 2005.

Bauman, Zygmunt. O mal estar da pós-modernidade. Rio de Janeiro: Jorge Zahar, 1998. Berger. Peter. O dossel sagrado. São Paulo: Paulus, 1985.

Bittencourt Filho, José. Matriz religiosa brasileira. Petrópolis: Vozes, 2003.

Bourdieu, Pierre. Meditações pascalianas. Rio de Janeiro: Bertrand Brasil, 2001.

CANCLini, Nestor Garcia. Culturas híbridas - estratégias para entrar e sair da modernidade. São Paulo: EdusP, 2006.

Carneiro, Sandra M. C. de Sá. Novas peregrinações brasileiras e suas interfaces com o turismo. Ciências Sociales e Religion/Ciências Sociais e Religião, ano 6, n. 6, p. 71-100, out. 2004.

CARvalHo, José Jorge. Características do fenômeno religioso na sociedade contemporânea.

In: Bingemer, Maria Clara C. (Org.). O impacto da modernidade sobre a religião. São Paulo: Loyola, 1992. p. 133-160.

Cunha, Euclides da. Os sertões. Belo Horizonte: CEDIC, 2005.

DROOGERs, André. A religiosidade mínima brasileira. Religião e Sociedade. Rio de Janeiro: ISER, 1987.

Freston, Paul. Protestantes e política no Brasil: da constituinte ao impeachment. 303 p. 1993. Tese (Doutorado em Ciências Sociais) - Unicamp, São Paulo, 1993.

GEERTZ, Clifford. A interpretação das culturas. Rio de Janeiro: LTC, 1989.

Giumbelli. Emerson. A presença do religioso no espaço público: modalidades no Brasil. Religião e Sociedade, Rio de Janeiro, v. 28, n. 2, p. 80-101, 2008.

Hervieu-Leger, Danièle. La religion en mouvement: le pèlerin et le converti. Paris: Flammarion, 1999.

MAFrA, Clara. Os evangélicos. Rio de Janeiro: Jorge Zahar Editora, 2001.

Machado, Maria das Dores Campos; Mariz, Cecília. Sincretismo e trânsito religioso: comparando carismáticos e pentecostais. Comunicações do Iser, n. 45, ano 13, p. 24-34, 1994.

Mariz, Cecília; Machado, Maria das Dores Campos. Mudanças recentes no campo religioso brasileiro. Rio de Janeiro: UERJ/UFRJ, 1998. Texto avulso. 
Montero, Paula. Religião, pluralismo e esfera pública no Brasil. Cebrap, v. 74, p. 47-65, 2006.

Novaes, Regina Reyes. Os escolhidos de Deus - Pentecostais, trabalhadores e cidadania. Rio de Janeiro: IsER, 1985.

Pierucci, Antônio Flávio. Cadê nossa diversidade religiosa? Comentários ao texto de Marcelo Camurça. In: Teixeira, Faustino; Menezes, Renata (Org.). As religiões no Brasil. Petrópolis: Vozes, 2006a.

. Ciências sociais e religião - a religião como ruptura. In: TeIxeIra, Faustino; Menezes, Renata (Org.). As religiões no Brasil, continuidades e rupturas. Petrópolis: Vozes, 2006b.

SANchis, Pierre. As religiões dos brasileiros. Horizontes, v. 1, n. 2, 1998.

Cultura brasileira e religião - passado e atualidade. Cadernos Ceru, São Paulo, USP, Série 2, v. 19, n. 2, p. 71-92, dez. 2008.

SANTos, Boaventura de Souza. Pela mão de Alice - o social e o político na pós-modernidade. São Paulo: Cortez, 1997.

SiLva, Vagner Gonçalves. Concepções religiosas afro-brasileiras e neopentecostais: uma análise simbólica. Revista USP, n. 67, p. 150-174, set./nov. 2005.

Silveira, Emerson Sena da; Своснет, Eduardo. Modernidade(s) e religião: rupturas, permanências e combinações. Sociedade e Cultura, v. 6, p.27-38, 2006.

SoARes, Luiz Eduardo. Os dois corpos do presidente e outros ensaios. Rio de Janeiro: Relume-Dumará, 1993.

Steil, Carlos Alberto. Catolicismo e cultura. In: VAlLa, Victor Vincent (Org.). Religião e cultura popular. Rio de Janeiro: DP\&A, 2001.

Weber, Max. Économie et société. Paris: Plon, 1971. t. 1.

. Ensaios de sociologia. In: . Os pensadores. São Paulo: Abril Cultural, 1974. p. 239-270.

Recebido para publicação em 09/06/12. Aceito para publicação em 10/12/12. 
